Славяноведение 2013-2023

ISSN 2079-8784

URL - $\underline{\text { http://ras.jes.su }}$

Все права защищены

Номер 5 Том . 2018

\title{
Советский Союз и польское военно-политическое подполье. Апрель 1943 - декабрь 1945. Т. 2. Ч. 1. Варшавское восстание. Июль-ноябрь 1944 г. Документы
}

Парсаданова В. С.

Аннотация

Ключевые слова:

Дата публикации: 06.11.2018

Ссылка для цитирования:

Парсаданова В. С. Советский Союз и польское военно-политическое подполье. Апрель 1943 - декабрь 1945. Т. 2. Ч. 1. Варшавское восстание. Июль-ноябрь 1944 г. Документы // Славяноведение - 2018. - Номер 5 С. 124-128 [Электронный pecypc]. URL: https://slav.jes.su/S0869544X0000858-6-1 (дата обращения: 26.04.2023). DOI: 10.31857/S0869544X0000858-6 


\section{Parsadanova}

Abstract

Keywords:

Publication date: 06.11 .2018

\section{Citation link:}

Parsadanova V. // Slavianovedenie - 2018. - Issue 5 C. 124-128 [Electronic resource]. URL: https://slav.jes.su/S0869544X0000858-6-1 (circulation date: 26.04.2023). DOI: 10.31857/S0869544X0000858-6

Код пользователя: 0; Дата выгрузки: 26.04.2023; URL - http://ras.jes.su/slav/s207987840000283-0-1-ru Bce права защищены. 